\title{
Development of a Problem-Based Learning Management System-Supported Smartphone (PBLMS3) Application Using the ADDIE Model to Improve Digital Literacy
}

\author{
Rahmat Rizal \\ Universitas Siliwangi, Indonesia \\ https://orcid.org/0000-0002-7509-7180
}

\author{
Dadi Rusdiana, Wawan Setiawan and Parsaoran Siahaan \\ Universitas Pendidikan Indonesia, Indonesia \\ https://orcid.org/0000-0002-1172-1730 \\ https://orcid.org/0000-0003-4016-4125 \\ https://orcid.org/0000-0002-7611-9636
}

\begin{abstract}
This research aims to describe the development process of a problem-based learning management system-supported smartphone (PBLMS3) application using the ADDIE Model (analysis, design, development, implementation, and evaluation) and to determine its effectiveness in improving digital literacy. Data were collected from 40 physics education students in Tasikmalaya, consisting of 13 males and 27 females with an average age of 20 years. Data collection techniques included a literature study, expert validation, digital literacy test, and a questionnaire on student perceptions. Expert validation was obtained from three experts using a Likert scale and processed by the validation value equation developed by Aiken. The expert validation resulted in a value of 0.92 , which met the minimum validation requirements. Furthermore, the effectiveness of the PBLMS3 application in improving digital literacy in online physics learning was determined by a statistical process using the Wilcoxon test. Based on its results, the t-value was -0.4752 , with a p-value of $0.00<0.05$. This means that the PBLMS3 application is effective for and capable of improving students' digital literacy. Further research is recommended to determine other factors capable of improving digital literacy.
\end{abstract}

Keywords: digital literacy; learning management system; online physics learning; problem-based learning

*Corresponding author: Dadi Rusdiana, dadirusdiana@upi.edu 


\section{Introduction}

Information and communication technology (ICT) is rapidly developing, significantly impacting people's lifestyles and community needs in various fields (Rizal et al. 2020a; Shopova, 2014). According to Rizal et al. (2019), teachers need to become professional educators to utilize ICT to organize educational development activities. Technology in the educational world is manifested in learning reformation. Furthermore, the need to utilize it in teaching students was influenced by the fact that external communities were already familiar with its use in communication, information searching, and various commercial activities. Technology is an important strategic media tool used to support the achievement of learning-reformation goals.

Technology plays three main roles in the learning process. It creates pleasant and exciting learning conditions. It also equips students with the ability to use high technology. Furthermore, it functions as a learning tool with application programs used to simplify and speed up work as well as increase variation and interpretation techniques (Susilawati et al., 2020). One of the skills in using technology in educational activities encompasses digital literacy, which relates to the competencies and skills needed to use the internet, ICT, and media. Its main focus is problem-solving and knowledge-building through technology and media in a critical, creative, flexible, and ethical manner (Ferrari, 2012). Vuorikari et al. (2016) stated that digital literacy competence consists of information and data literacy, communication and collaboration, digital content creation, e-safety, and problem-solving. Meanwhile, Rizal et al. (2020b) reported that one can be trained in digital literacy through a physics learning process covering three areas of competence, namely information and data literacy, communication and collaboration, and digital content creation.

According to several preliminary studies, many physics education students have low digital literacy. For instance, the research carried out by Kurniawati and Baroroh (2016) in Bengkulu found that the digital literacy of physics education students was "basic", with a medium ability to operate, analyze, and communicate through the media. In Merauke, Nikat (2020) also found that students' digital literacy was low and required the development of lectures to provide space for training. Furthermore, Rizal et al.'s (2020c) research in Tasikmalaya also found that physics education students had low digital literacy, with an average score of 50 . In detail, the study found that the mean literacy competencies of information and digital data, communication and collaboration, and digital content creation were 36 (low), 68 (medium), and 47 (low), respectively.

Amhag et al. (2019) recommended the use of technology in learning activities to train digital literacy. According to He (2014), using technology strengthens one's confidence in online learning and trains student teacher candidates in using ICT for their future classes. Learning management systems (LMSs) to assist learning administration have been widely used in e-learning content platforms (Gutman, 2017). An LMS allows students to learn wider, irrespective of the time and location. The learning material is also more varied in words (text), visual, audio, 
and motion, better known as multimedia (Kean et al., 2012). An LMS has various functions in learning and training activities. It has to: 1) concentrate and automate administration, 2) provide personal services and guidelines, 3) arrange and present learning content regularly, 4) support portability and better standardization, and 5) manage reusable learning content (Raza et al., 2021).

LMSs have already provided positive benefits for their users, especially in academic achievements. In a study by Marineo and Shi (2019), the literacy module integrated into the LMS had a positive impact on the students' academic achievements. Mijatovic et al. (2013) stated that students using an LMS had better performance and academic achievements. Theoretically, the LMS provides several benefits and diverse effects due to the inappropriate design of lectures. In most cases, students are confused about what they have to do, making it difficult to achieve their learning goals (Emmamoge et al., 2020). An LMS makes learning slow and boring and focuses more on administration (Cho et al., 2014). Additionally, Abuhassna et al. (2020) stated that the use of Moodle (an LMS) in learning does not provide optimal outcomes due to its inability to achieve usability and reliability. We analyzed the various weaknesses of the existing LMSs. Firstly, LMSs function as a face-to-face learning support media facilitated by administrative learning. Secondly, it is unable to support synchronous online learning, thereby making it less interactive. Thirdly, it is unable to facilitate lectures by fully implementing learning models or methods. Lastly, it is unable to facilitate strict learning supervision, thereby reducing students' learning motivation and frustrating their success in achieving the lecture goals.

Due to the various weaknesses of LMSs, it is necessary to develop an independent system capable of facilitating synchronous online learning by applying specific models. Problem-based learning (PBL) is one of the recommended models in physics learning. According to Ceker and Ozdamli (2016), the various characteristics of PBL are as follows: 1) learning is student-centered, 2) authentic problems are used to focus on learning, 3) new information is acquired through self-directed learning, 4) learning occurs in small groups, and 5) teachers act as facilitators.

The characteristics of PBL strongly encourage users to search for valid and relevant information, collaborate and communicate in groups, and generate creativity in problem-solving. All of these activities provide a positive learning environment to practice digital literacy. Therefore, the learning process carried out through the LMS is directed by using PBL syntax. Due to the benefits of PBL in optimizing digital literacy, it is necessary to integrate the PBL syntax into the LMS. Barrett (2017) developed PBL syntax, which can be adapted into the LMS through the following five stages:

1. Problem-finding: Students discover the problems they find independently.

2. Group discussion: Students engage in group discussions to clarify problems, define them, exchange ideas based on their understanding, and determine the things needed to solve the problem.

3. Independent exploration: Students conduct independent studies related to the problem by searching for information in libraries, databases, the internet, 
personal sources, or making observations.

4. Problem-solving: Students return to the initial group discussion to exchange information, learn from peers, and work together to solve problems.

5. Presentation of results: Students present the solutions found individually and evaluate the learning activities together in class.

A smartphone is one of the most reliable online digital devices due to its ease of use (Turnbull et al., 2019). An LMS with smartphones provides new meaning in learning activities (Dreamson et al., 2018) and develops scientific inquiry and digital literacy (Marty et al., 2013). According to Alhasanat (2019), smartphones provide numerous benefits, such as supporting independent and collaborative learning experiences, eliminating the rigidity of learning experiences and involving lazy students, improving focus for longer periods of time, providing flexible and efficient learning, as well as facilitating positive flexibility to students with visual or audio deficiencies.

Because of LMS advantages, it is necessary to develop an innovative LMS by integrating synchronous learning activities using PBL. This has led to the development of the problem-based learning management system-supported smartphone (PBLMS3) application capable of fulfilling the needs of the newest LMS. These needs include online synchronous learning activities at a scheduled time, virtual experiments, information engine search, and synchronous collaboration room. The PBLMS3 application was developed using the ADDIE Model, which is a series of instructional design processes consisting of five stages, namely analysis, design, development, implementation, and evaluation (Reinbold, 2013). These five stages are guidelines for the makers of an efficient learning application. This model was chosen because it is often used to describe a systematic approach to instructional development as a result of its sequential and interactive processes.

This research has two main objectives, namely to explain the development of the PBLMS3 application and to ascertain the effectiveness of the PBLMS3 application to improve digital literacy.

\section{Method}

This research used the ADDIE Model, which consists of five steps, analysis, design, development, implementation, and evaluation. The activities carried out at each stage of the ADDIE Model are explained in Table 1.

Table 1: Research activities in every stage of the ADDIE Model

\begin{tabular}{|c|l|l|}
\hline No. & \multicolumn{1}{|c|}{ Stage } & \multicolumn{1}{c|}{ Activities } \\
\hline 1 & Analysis & - Study students' digital literacy \\
& & - Analyze LMS for online physics learning \\
& & - Study PBL for online physics learning \\
\hline 2 & Design & - Design a PBLMS3 application flowchart \\
& & - $\begin{array}{l}\text { Design a PBLMS3 application storyboard } \\
\text { Design PBLMS3 application material content }\end{array}$ \\
\hline
\end{tabular}




\begin{tabular}{|c|l|l|}
\hline No. & \multicolumn{1}{|c|}{ Stage } & \multicolumn{1}{c|}{ Activities } \\
\hline 3 & Development & $\begin{array}{l}\text { Develop the PBLMS3 application by professional } \\
\text { programmers } \\
\text { Fill in the content of the PBLMS3 application according } \\
\text { to the learning objective } \\
\text { Validate the PBLMS3 application by pedagogical and } \\
\text { media experts }\end{array}$ \\
\hline 4 & Implementation & $\begin{array}{l}\text { Conduct brief socialization and training in using the } \\
\text { PBLMS3 application } \\
\text { Conduct synchronous learning } \\
\text { Test digital literacy through the PBLMS3 application }\end{array}$ \\
\hline 5 & Evaluation & $\begin{array}{l}\text { Analyze the strengths and weaknesses of the PBLMS3 } \\
\text { application } \\
\text { Collect data on students' perceptions }\end{array}$ \\
\hline
\end{tabular}

This research involved three experts in learning media and pedagogy as well as 40 physics education students, consisting of 13 males and 27 females in the third semester at a university in Tasikmalaya, a city in the province of West Java, Indonesia. The instruments used in this research were a digital literacy multiple-choice test, expert validation, and a student perception questionnaire.

The digital literacy multiple-choice test used in this research was a valid and reliable test developed in previous studies conducted on pre-service physics teachers in Tasikmalaya. The test accommodates three competency areas, namely digital data and information literacy, communication and collaboration, and digital content creation (Rizal et al., 2020d). The expert validation questionnaire and student perception questionnaire evaluated the PBLMS3 application using a five-point Likert scale. The validation of the PBLMS3 application was determined using the Aiken validation value (Equation 1) (Aiken, 1985).

In the equation, $V$ denotes the validation value, $s$ the difference between the expert

$$
V=\frac{\sum s}{n(c-1)}
$$

and lowest scores, $n$ the number of experts (evaluators), and $c$ the highest value on the scale. The PBLMS3 application will be considered a valid media assuming it meets the minimum validation value requirements depending on the number of evaluators and rating categories, as shown in Table 2 (Anggraini et al., 2020).

Table 1: Aiken minimum validation value

\begin{tabular}{|c|c|c|c|c|c|c|c|c|c|c|}
\hline Item no. & \multicolumn{10}{|c|}{ Number of rating categories } \\
\hline $\begin{array}{c}\text { Evaluator } \\
(\mathbf{n})\end{array}$ & \multicolumn{2}{|c|}{$\mathbf{3}$} & $\mathbf{4}$ & $\mathbf{4}$ & $\mathbf{5}$ & $\mathbf{6}$ & \multicolumn{2}{|c|}{$\mathbf{7}$} \\
\cline { 2 - 12 } & $\mathbf{V}$ & $\mathbf{p}$ & $\mathbf{V}$ & $\mathbf{p}$ & $\mathbf{V}$ & $\mathbf{p}$ & $\mathbf{V}$ & $\mathbf{p}$ & $\mathbf{V}$ & $\mathbf{p}$ \\
\hline 2 & & & & & 1.00 & 0.040 & 1.00 & 0.028 & 1.00 & 0.02 \\
\hline 3 & & & & & 1.00 & 0.008 & 1.00 & 0.005 & 1.00 & 0.003 \\
\hline 3 & 1.00 & 0.037 & 1.00 & 0.016 & 0.92 & 0.32 & 0.87 & 0.046 & 0.89 & 0.029 \\
\hline 4 & & & 1.00 & 0.004 & 0.94 & 0.008 & 0.95 & 0.004 & 0.92 & 0.006 \\
\hline 4 & 1.00 & 0.012 & 0.92 & 0.020 & 0.88 & 0.024 & 0.85 & 0.027 & 0.83 & 0.029 \\
\hline
\end{tabular}


The student perception questionnaire was used to determine the percentage of students' acceptance based on their experience in using the PBLMS3 application at the implementation stage.

An analysis of digital literacy scores from the pre-test and the post-test was conducted to determine the effectiveness of the PBLMS3 application. A parametric test using paired $\mathrm{t}$-test is performed supposing the data are normally distributed. Conversely, a data non-parametric test using Wilcoxon is carried out when data are not normally distributed.

\section{Results and Discussion}

The development of the PBLMS3 application in this research was analyzed using the ADDIE Model, where all stages of development intersect and have an impact on each other. The changes in one stage affect the others, therefore they need to be performed in synergy (Aldoobie, 2015).

\subsection{Analysis}

In the analysis stage, the problem is identified and the student needs are determined. According to Cheung (2016), the educator needs to craft educational objectives and determine what needs to be taught to accomplish set goals. The analysis stage consisted of many activities. The first was to study the three most important aspects of students' digital literacy in the first semester. In a study by Rizal et al. (2020b), the competencies of information and digital data, communication and collaboration, and digital content creation were scored 36 (low), 68 (medium), and 47 (low). Students' habits in utilizing digital devices influenced these values.

The second activity was to analyze LMSs for learning development in online physics, which provides synchronous online learning activities to facilitate students' training in digital literacy and provide online virtual experiments (Susilawati et al., 2020). Table 3 provides a detailed analysis of the use of the PBLMS3 application in online physics learning.

Table 2: Needs analysis of the PBLMS3 application in online physics learning

\begin{tabular}{|c|l|l|l|}
\hline No. & \multicolumn{1}{|c|}{ Competency } & \multicolumn{1}{|c|}{ Student activities } & \multicolumn{1}{|c|}{$\begin{array}{c}\text { Features needed in the } \\
\text { PBLMS3 application }\end{array}$} \\
\hline 1 & $\begin{array}{l}\text { Browsing, searching } \\
\text { and filtering } \\
\text { information and } \\
\text { digital content }\end{array}$ & $\begin{array}{l}\text { Search for valid and } \\
\text { credible information } \\
\text { related to the topic or } \\
\text { problem }\end{array}$ & $\begin{array}{l}\text { Availability of an information } \\
\text { search engine integrated with } \\
\text { the PBLMS3 application }\end{array}$ \\
\hline 2 & $\begin{array}{l}\text { Storing data, } \\
\text { information, and } \\
\text { digital content }\end{array}$ & $\begin{array}{l}\text { Store information in } \\
\text { easily accessible spaces }\end{array}$ & $\begin{array}{l}\text { Availability of storage space } \\
\text { to save and report search } \\
\text { results }\end{array}$ \\
\hline 3 & $\begin{array}{l}\text { Evaluating data, } \\
\text { information, and } \\
\text { digital content }\end{array}$ & $\begin{array}{l}\text { Filter information using } \\
\text { comparative sources }\end{array}$ & $\begin{array}{l}\text { Availability of an information } \\
\text { search engine integrated with } \\
\text { the PBLMS3 application }\end{array}$ \\
\hline 4 & $\begin{array}{l}\text { Sharing information } \\
\text { through digital } \\
\text { technologies }\end{array}$ & $\begin{array}{l}\text { Be actively involved in } \\
\text { scientific discussions by } \\
\text { paying attention to the } \\
\text { ethics of digital } \\
\text { communication }\end{array}$ & $\begin{array}{l}\text { Availability of discussion } \\
\text { space in limited groups or in } \\
\text { one large class that are } \\
\text { interactive and synchronous. } \\
\text { The lecturer can monitor the }\end{array}$ \\
\hline 5 & $\begin{array}{l}\text { Interacting through } \\
\text { digital technologies }\end{array}$ \\
\hline
\end{tabular}




\begin{tabular}{|c|l|l|l|}
\hline No. & \multicolumn{1}{|c|}{ Competency } & \multicolumn{1}{|c|}{ Student activities } & \multicolumn{1}{|c|}{$\begin{array}{c}\text { Features needed in the } \\
\text { PBLMS3 application }\end{array}$} \\
\hline 6 & $\begin{array}{l}\text { Engaging in } \\
\text { citizenship through } \\
\text { digital technologies }\end{array}$ & $\begin{array}{l}\text { Solve problems based } \\
\text { on facts and also valid } \\
\text { and credible information }\end{array}$ & $\begin{array}{l}\text { discussion room to achieve } \\
\text { the objectives of the lecture. } \\
\text { Interactions between students } \\
\text { or students and lecturers. }\end{array}$ \\
\hline 7 & The netiquette & $\begin{array}{l}\text { Availability of file storage } \\
\text { space to store reports of } \\
\text { content in various } \\
\text { formats }\end{array}$ & $\begin{array}{l}\text { Engage in virtual } \\
\text { physics experiment } \\
\text { activities } \\
\text { formats }\end{array}$ \\
\hline 9 & $\begin{array}{l}\text { Copyright and } \\
\text { licenses }\end{array}$ & $\begin{array}{l}\text { Report their activities in } \\
\text { various formats using } \\
\text { Word, Excel, and } \\
\text { PowerPoint by } \\
\text { capturing data sources } \\
\text { or supporting } \\
\text { information }\end{array}$ & \\
\hline
\end{tabular}

The third activity in the analysis stage was a study of PBL for online learning. A literature study was carried out at this stage to learn the PBL syntax integrated into the LMS and its advantages in learning activities.

\subsection{Design}

After collecting references and performing a needs analysis of LMSs, we made a PBLMS3 application design consisting of home, pre-test, post-test, learning process, and learning material at the design stage. The pre- and post-tests provided space to capture questions in the form of multiple choice and essays. The PBL syntax was integrated into the learning process by applying five learning steps, namely problem-finding, discussion in small groups, independent exploration, problem-solving, and presentation of results. The learning process follows the synchronous learning system regulated by the PBLMS3 application only when the lecturer opens a learning space with a sequential timeframe. The PBL model was integrated with the PBLMS3 application because it is considered to have the right characteristics needed to achieve the learning objective. The characteristics of PBL are student-centered learning, using authentic problems to focus on learning, requiring new information through self-directed learning, teacher as a facilitator, and group learning (Ceker \& Ozdamli, 2016).

Figure 1 depicts a system flowchart designed to visualize the design of the PBLMS3 application integrated with PBL. 


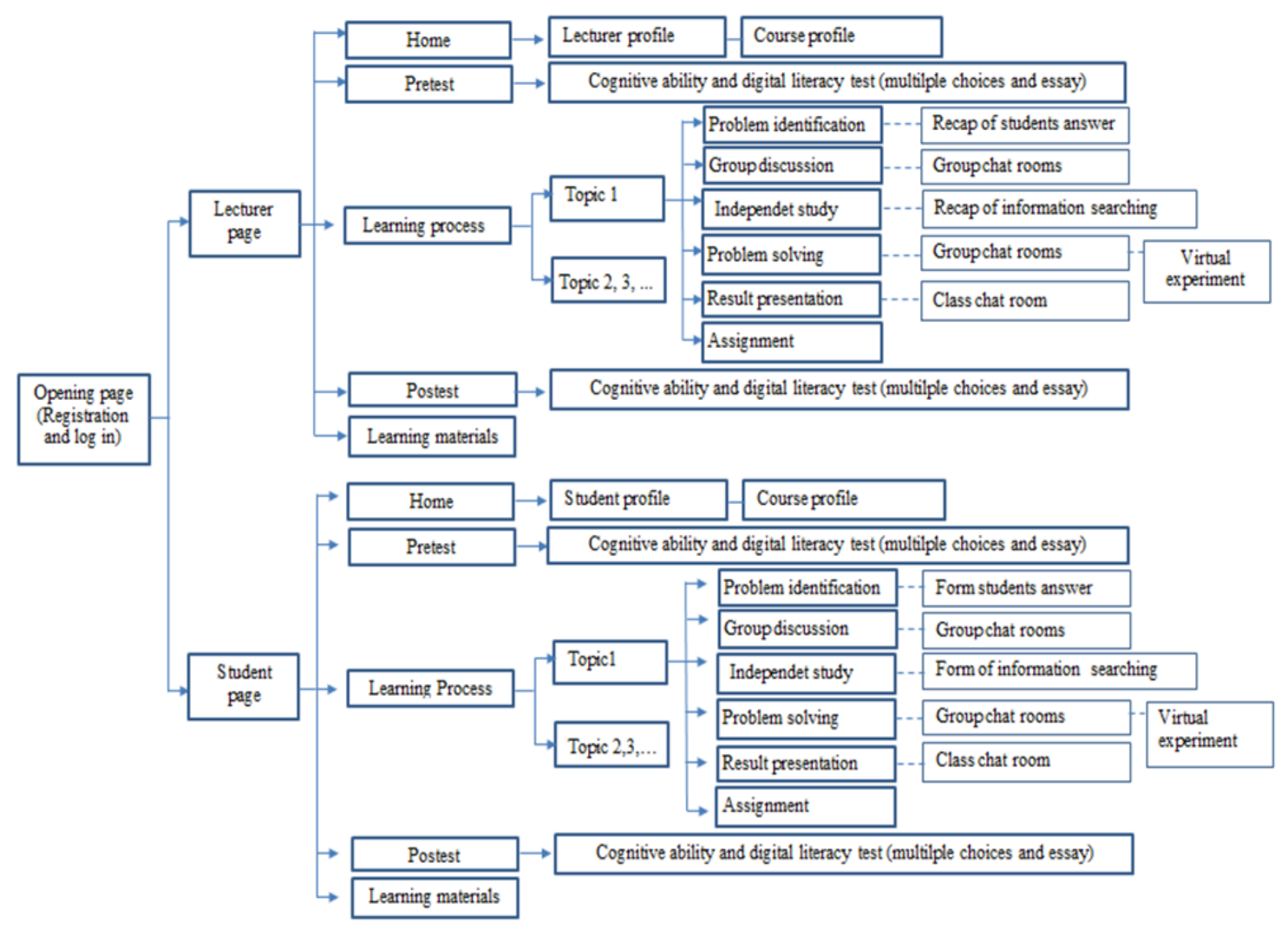

Figure 1: Flowchart system of the PBLMS3 application for physics school lectures

After creating a flowchart, the next step was to design a storyboard, which is where illustrations are displayed sequentially to visualize a program or an application. During the design phase, activity scenarios were added to the main ideas on user requirements to determine high-level functionality introduced by new systems that are capable of inherently influencing current user activity. Furthermore, in creating a storyboard, the designer creates information design scenarios to determine object representations and task actions to help users understand and interpret the proposed functionality (Mou et al., 2013). The storyboard used brings up the display design and the functions of each part of the LMS displayed. An example of the storyboard for each page is shown in Figure 2.

The material used in the PBLMS3 application is for online physics learning. It is limited to dynamic electricity with three main concepts, namely electric current and Ohm's law, the electrical resistance of a conductor, and a series-parallel circuit. 


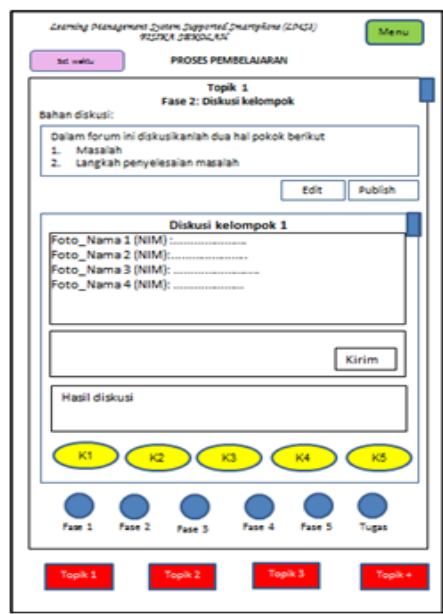

(a)

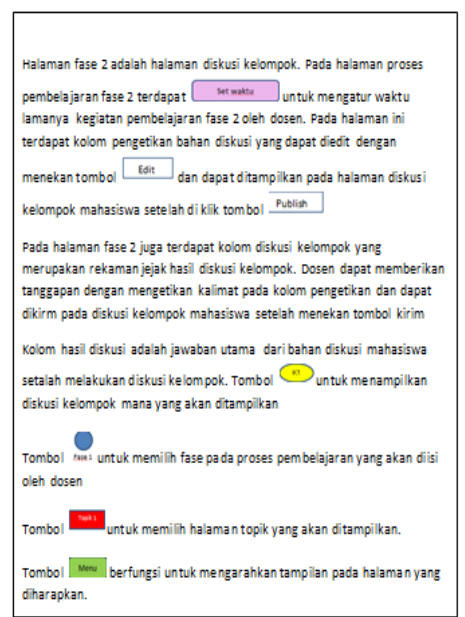

(b)

Figure 2: The example storyboard made to develop the PBLMS3 application

(a) Example of page views designed in developing the PBLMS3 application, and

(b) Example of page description and function for each PBLMS3 icon

\subsection{Development}

The activities at the development stage include creating resources and preparing program or application readiness (Baharuddin, 2018). The storyboard was prepared, submitted, and discussed with professional programmers. During the development process, each part of the page was separately compiled, and the production process was completed in four months. The PBLMS3 application was developed as a web-based application that can be accessed from various digital devices. However, in this study, its use focuses on smartphones. This application is accessible on the website http://lms3.saena.web.id/ and can be downloaded at http://lms3.saena.web.id/LMS3.apk. Several of the page displays on the PBLMS3 application after completion are shown in Figure 3.
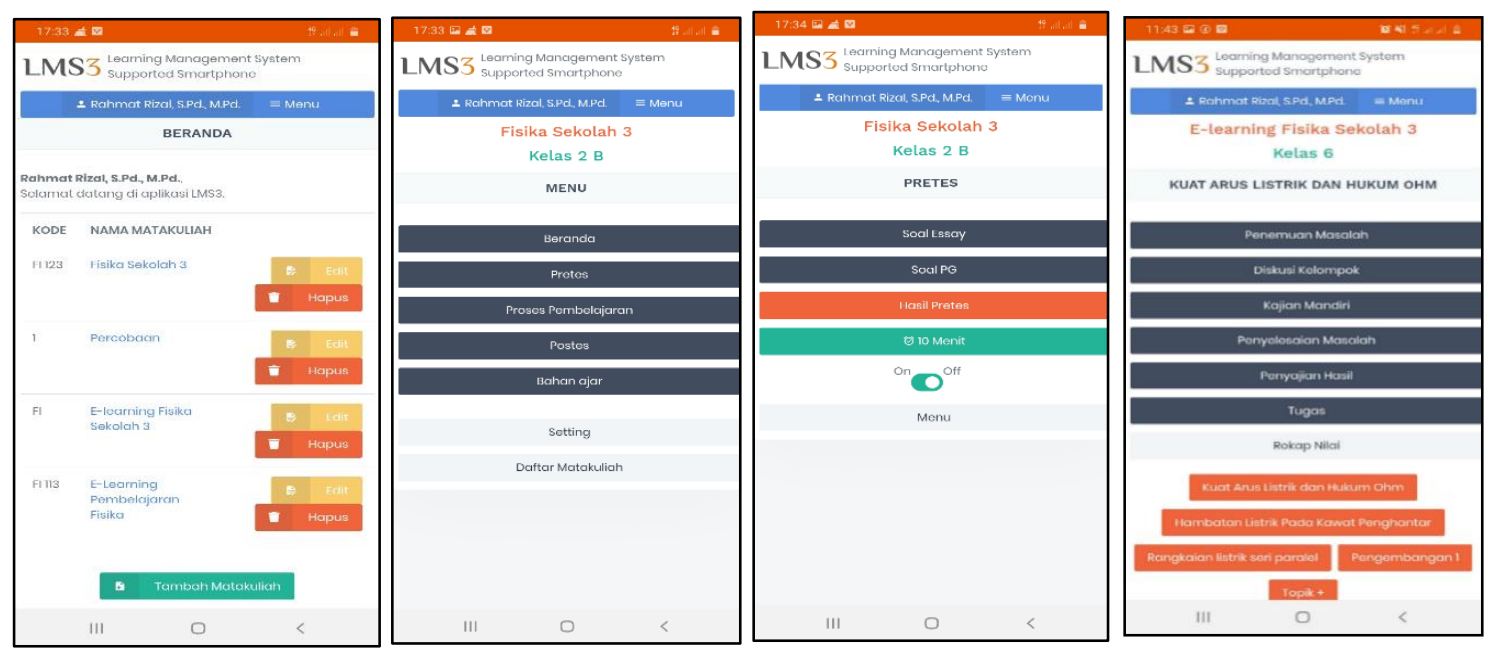

Figure 3: Examples of page displays of the PBLMS3 application

An assessment of the seven important items related to the PBLMS3 application was needed to determine the LMS quality. These items are layout, user interaction, usability, navigation, typography, learning process, and material 
substance. The expert validation was based on a five-point Likert scale. Assessment of the PBLMS3 application was performed by media and pedagogical experts, with results according to the Aiken validation value (equation 1). The results of the expert validation of the PBLMS3 application are shown in Table 4.

Table 3: Expert validation of PBLMS3 application items

\begin{tabular}{|c|c|c|c|c|c|c|c|c|c|c|c|c|c|c|}
\hline \multirow{2}{*}{ 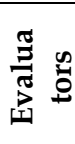 } & \multicolumn{2}{|c|}{ Layout } & \multicolumn{2}{|c|}{$\begin{array}{c}\text { User } \\
\text { interaction }\end{array}$} & \multicolumn{2}{|c|}{ Usability } & \multicolumn{2}{|c|}{ Navigation } & \multicolumn{2}{|c|}{ Typography } & \multicolumn{2}{|c|}{$\begin{array}{c}\text { Learning } \\
\text { process }\end{array}$} & \multicolumn{2}{|c|}{$\begin{array}{c}\text { Material } \\
\text { substance }\end{array}$} \\
\hline & $\mathbf{R}$ & $\mathbf{s}$ & $\mathbf{R}$ & $\mathbf{s}$ & $\mathbf{R}$ & $\mathbf{s}$ & $\mathbf{R}$ & $\mathbf{s}$ & $\mathbf{R}$ & $\mathbf{s}$ & $\mathbf{R}$ & $\mathbf{s}$ & $\mathbf{R}$ & $\mathbf{s}$ \\
\hline 1 & 4 & 3 & 5 & 4 & 5 & 4 & 5 & 4 & 5 & 4 & 5 & 4 & 4 & 3 \\
\hline 2 & 5 & 4 & 4 & 3 & 5 & 4 & 5 & 4 & 5 & 4 & 5 & 4 & 5 & 4 \\
\hline 3 & 5 & 4 & 5 & 4 & 4 & 3 & 5 & 4 & 5 & 4 & 4 & 3 & 5 & 4 \\
\hline$\sum \mathrm{s}$ & \multicolumn{2}{|c|}{11} & \multicolumn{2}{|c|}{11} & \multicolumn{2}{|c|}{11} & \multicolumn{2}{|c|}{12} & \multicolumn{2}{|c|}{12} & \multicolumn{2}{|c|}{11} & \multicolumn{2}{|c|}{11} \\
\hline $\mathrm{V}$ & \multicolumn{2}{|c|}{0.92} & \multicolumn{2}{|c|}{0.92} & \multicolumn{2}{|c|}{0.92} & \multicolumn{2}{|c|}{1} & \multicolumn{2}{|c|}{1} & \multicolumn{2}{|c|}{0.92} & \multicolumn{2}{|c|}{0.92} \\
\hline
\end{tabular}

The expert validation of the PBLMS3 application yielded V values of 0.92 for five items and 1 for the other two. The minimum criteria for a $\mathrm{V}$ value, as shown in Table 2, were thus met. Therefore, it was concluded that the PBLMS3 application had met the validity criteria and was ready to be implemented.

\subsection{Implementation}

During the implementation stage, the online physics learning activities were carried out using a one-group pre-test-post-test design (Creswell, 2012), as shown in Figure 4.

$$
01 \quad \mathrm{X} \quad 02
$$

Figure 4: Implementation design for online physics learning using the PBLMS3 application

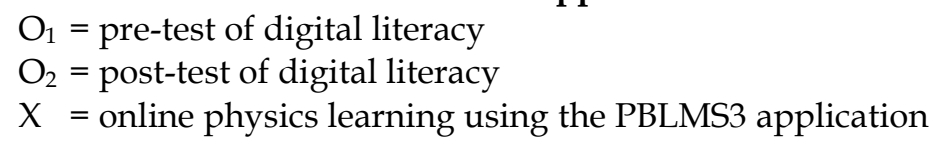

During the implementation stage, the PBLMS3 application was used by 40 physics education students to allocate time during the pre-test and post-test processes and after the lecturer had opened the system. The participants conducted learning processes sequentially for each stage, with repetition or jumping from one stage to another. The learning process automatically moves to the next stage when the time has been exhausted.

The digital literacy scores yielded for the implementation stage of the PBLMS3 application for online physics lectures are recapitulated in Table 5. 
Table 5: Digital literacy scores yielded during the implementation stage

\begin{tabular}{|l|c|c|l|l|l|l|l|l|l|}
\hline \multicolumn{3}{|c|}{ N } & Mean & Median & Mode & $\begin{array}{l}\text { Standard } \\
\text { deviation }\end{array}$ & Variance & Min & Max \\
\hline $\begin{array}{l}\text { Pre- } \\
\text { test }\end{array}$ & 40 & 0 & 63.00 & 57.00 & 51.00 & 12.74 & 132.62 & 51.00 & 75.00 \\
\hline $\begin{array}{l}\text { Post- } \\
\text { test }\end{array}$ & 40 & 0 & 85.50 & 86.00 & 85.00 & 6.52 & 38.92 & 74.00 & 96.00 \\
\hline
\end{tabular}

Shapiro Wilk was used to determine the results of the normality test of the digital literacy pre- and post-tests, as shown in Table 6.

Table 6: Result of the normality test using Shapiro Wilk

\begin{tabular}{|l|c|c|c|}
\hline \multicolumn{4}{|c|}{ Shapiro Wilk } \\
\hline & Statistic & df. & Sig. \\
\hline Pre-test & 0.69 & 40 & 0.000 \\
\hline Post-test & 0.875 & 40 & 0.007 \\
\hline
\end{tabular}

Based on the normality test results using Shapiro Wilk, the significance of the pre- and post-tests were 0.000 and 0.007 , respectively, with a p-value lower than 0.05. Therefore, it can be concluded that the pre- and post-test scores were abnormally distributed.

The effectiveness of the PBLMS3 application in improving digital literacy was analyzed using the Wilcoxon test, as shown in Table 7.

Table 7: Results of the application's effectiveness using the Wilcoxon test

\begin{tabular}{|c|c|}
\hline & Gain \\
\hline$Z$ & -0.4752 \\
\hline Asymp. Sig. (2-tailed) & 0.0000 \\
\hline
\end{tabular}

The Wilcoxon test yielded a $\mathrm{t}$-value of -0.4752 , and the p-value was $0.00<0.05$. This means that the PBLMS3 application was effective in improving participants' digital literacy.

According to Pöntinen and Räty-Záborszky (2020), it is necessary to involve technology in learning activities to optimize students' digital competence. Therefore, digital devices need to significantly feature during the learning process (Tejedor, 2020). Online physics learning activities using the PBLMS3 application can be performed with the support of digital devices, such as smartphones. Learning activities are carried out to allow students to optimize the use of smartphones, which have become more useful as learning media to improve digital literacy. Ilomäki et al. (2016) stated that teachers need to provide opportunities for their students to practice these digital competencies through complex, challenging, and authentic learning activities. Learning frameworks capable of training digital literacy also need to be practice-based, comprehensive, 
and oriented towards the required competencies and problem-solving (Guitert et al., 2020).

The PBLMS3 application, integrating PBL in the learning process, provides challenges in overcoming physics concepts and phenomena observed in everyday life. Therefore, participants tried to solve problems by searching, processing, analyzing, and synthesizing online information and then discussing it through online group discussion forums to exchange ideas and understand the concepts using the PBLMS3 application and digital devices. It also enabled them to carry out simple virtual-experiment activities to prove the problem-solving plan compiled together. The experiment results and their analysis need to be reported in Excel format and presented with PowerPoint. All stated activities use PBL syntax, which is oriented towards the digital literacy competencies observed in the study. This means that the three competency areas in digital literacy will be developed and facilitated through online physics learning using the PBLMS3 application (Rizal et al., 2021).

\subsection{Evaluation}

At the evaluation stage, the advantage of the PBLMS3 application in online physics learning and students' perceptions were examined. We identified the following advantages of the PBLMS3 application in online physics learning:

1. It realizes innovative and quality lectures while providing better learning outcomes.

2. Learning activities can be held anywhere without being limited by the lecture room.

3. It creates a more interactive and fun learning atmosphere.

4. It engages students to express their opinions through group and classroom discussions.

5. It helps the lecturer to assess the process and the results of learning.

We also identified the following obstacles:

1. Some participants were late in conducting online learning activities at every stage.

2. Access to the PBLMS3 application was occasionally interrupted by weak network conditions.

The questionnaire on student perceptions consisted of a number of statements related to the PBLMS3 application as well as participants' changes in knowledge and skills. Students' perceptions are valuable in the evaluation process because they directly experience the implemented program (Ceroni et al., 2016; Rizal et al., 2020d). The main perception of participants was that the PBLMS3 application and the learning process needed improving for the user to be satisfied when using the application. The results of participants' perceptions are shown in Table 8. 
Table 8: Results of students' perceptions

\begin{tabular}{|c|c|c|c|c|c|c|c|}
\hline \multirow{2}{*}{ No } & \multirow{2}{*}{ Statement } & \multicolumn{5}{|c|}{ Percentage of student responses (\%) } & \multirow{2}{*}{ Mean } \\
\hline & & $\begin{array}{c}\begin{array}{c}\text { Strongly } \\
\text { agree }\end{array} \\
\text { ent }\end{array}$ & Agree & Neutral & Disagree & $\begin{array}{l}\text { Strongly } \\
\text { disagree }\end{array}$ & \\
\hline 1 & $\begin{array}{l}\text { The PBLMS3 application } \\
\text { is easy to use }\end{array}$ & 30 & 57.5 & 7.5 & 5 & 0 & 4.13 \\
\hline 2 & $\begin{array}{l}\text { The PBLMS3 application } \\
\text { is easy to download }\end{array}$ & 50 & 42.5 & 2.5 & 2.5 & 2.5 & 4.35 \\
\hline 3 & $\begin{array}{l}\text { The PBLMS3 application } \\
\text { operates smoothly on the } \\
\text { device }\end{array}$ & 42.5 & 37.5 & 10 & 10 & 0 & 4.13 \\
\hline 4 & $\begin{array}{l}\text { The display on the } \\
\text { PBLMS3 application is } \\
\text { simple and attractive }\end{array}$ & 65 & 27.5 & 5 & 2.5 & 0 & 4.55 \\
\hline 5 & $\begin{array}{l}\text { The combination of } \\
\text { colors presents a } \\
\text { harmonious display }\end{array}$ & 40 & 45 & 7.5 & 2.5 & 2.5 & 4.10 \\
\hline 6 & $\begin{array}{l}\text { The letters used in the } \\
\text { application are easy to } \\
\text { read }\end{array}$ & 75 & 22.5 & 2.5 & 0 & 0 & 4.73 \\
\hline 7 & $\begin{array}{l}\text { The display menu in the } \\
\text { application is attractive } \\
\text { and interactive }\end{array}$ & 55 & 40 & 5 & 0 & 0 & 4.50 \\
\hline 8 & $\begin{array}{l}\text { The navigation is clear } \\
\text { and works well }\end{array}$ & 72.5 & 15 & 10 & 2.5 & 0 & 4.58 \\
\hline 9 & $\begin{array}{l}\text { Virtual experiments can } \\
\text { be accessed and used } \\
\text { easily }\end{array}$ & 50 & 40 & 0 & 7.5 & 2.5 & 4.28 \\
\hline 10 & $\begin{array}{l}\text { The PBLMS3 application } \\
\text { presents online lectures } \\
\text { interactively }\end{array}$ & 67.5 & 25 & 2.5 & 5 & 0 & 4.55 \\
\hline 11 & $\begin{array}{l}\text { The PBLMS3 application } \\
\text { provides communication } \\
\text { facilities between users } \\
\text { during lectures }\end{array}$ & 60 & 27.5 & 10 & 0 & 2.5 & 4.43 \\
\hline 12 & $\begin{array}{l}\text { The PBLMS3 application } \\
\text { increases learning } \\
\text { motivation }\end{array}$ & 77.5 & 20 & 0 & 2.5 & 0 & 4.73 \\
\hline 13 & $\begin{array}{l}\text { The PBLMS3 application } \\
\text { provides a new } \\
\text { atmosphere in lecture } \\
\text { activities }\end{array}$ & 87.5 & 7.5 & 5 & 0 & 0 & 4.83 \\
\hline 14 & $\begin{array}{l}\text { The PBLMS3 application } \\
\text { is integrated in learning } \\
\text { and supports mastery of } \\
\text { concepts }\end{array}$ & 52.5 & 42.5 & 0 & 2.5 & 2.5 & 4.40 \\
\hline 15 & $\begin{array}{l}\text { The PBLMS3 application } \\
\text { facilitates skills in digital } \\
\text { literacy literacy }\end{array}$ & 65 & 35 & 0 & 0 & 0 & 4.65 \\
\hline
\end{tabular}


The information in Table 8 shows that the average perception of participants regarding the PBLMS3 application is above 4, which means that their level of agreement is high. Therefore, the PBLMS3 application, which was applied in online physics learning, received a positive rating from the participants. The participants' perceptions expressed through the questionnaire were reinforced by representative sample interviews, which provided several main points. Most of the participants were motivated by the PBLMS3 application in online physics learning because they can carry out synchronous online learning. This activity uses systematic and mutually supportive stages to stimulate students to practice problem-solving activities supported by valid internet-sourced information. Every idea to solve a problem needs to be proven using virtual experimental activities and communicated in group and class discussions without rejecting the opinions of others. Students need to also focus on the learning process because synchronous learning activities are very strict in managing time. The PBLMS3 application was well received by the participants because during the learning process, they were assessed continuously. Furthermore, it provides an access link to conduct virtual experiments for students to carry out observations, process data, and report experiments in one system.

\section{Conclusion}

The PBLMS3 application is an application that provides synchronous online learning and is practically accessible using a smartphone. The PBLMS3 application was developed using the ADDIE Model and has several advantages when implemented in online lectures. Field and literature studies were conducted at the analysis stage to collect information regarding previous profile digital literacy, PBL, and LMSs for online physics learning. At the design stage, the flowchart, storyboard, and material content of the PBLMS3 application were arranged. The development stage involved the production and validation of the PBLMS3 application by experts. The next stage was the implementation stage, where digital literacy tests and online synchronous learning were conducted. Lastly, participants' perceptions were collected at the evaluation stage, and the strengths and weaknesses of the PBLMS3 application were analyzed.

All online physics learning activities using the PBLMS3 application provide a learning environment that allows students to practice various digital literacy competencies. Online physics learning using the PBLMS3 application is a development that creatively meets students' educational needs. The results of this study can also be used as a reference in developing professional teachers that use technology for learning purposes. Further studies need to be conducted to identify factors that support online physics learning using the PBLMS3 application to improve digital literacy.

\section{Funding}

This research was funded by the Deputy for Research Strengthening and Development, Ministry of Research and Technology, and the National Research and Innovation Agency, Republic of Indonesia, through the doctoral dissertation grant. 


\section{References}

Abuhassna, H., Al-Rahmi, W. M., Yahya, N., Zahiri, M. A., Zakaria, M., Kosnin, A. B. M., \& Darwish, M. (2020). Development of a new model on utilizing online learning platforms to improve students' academic achievements and satisfaction. International Journal of Educational Technology in Higher Education, 17(38), 1-23. https://doi.org/https://doi.org/10.1186/s41239-020-00216-z

Aiken, L. R. (1985). Three coefficients for analysing reliability and validity of rating. Educational and Psychological Measurement, 45, 131-142. https://doi.org/10.1177/07399863870092005

Aldoobie, N. (2015). ADDIE Model. American International Journal of Contemporary Research, 5(6), 361-373.

http://www.aijcrnet.com/journals/Vol_5_No_6_December_2015/10.pdf

Alhasanat, I. K. (2019). Using smartphones in learning Arabic by AOU students. Higher Education Studies, 10(1), 48-59. https://doi.org/10.5539/hes.v10n1p48

Amhag, L., Hellström, L., \& Stigmar, M. (2019). Teacher educators' use of digital tools and needs for digital competence in higher education. Journal of Digital Learning in Teacher Education, 35(4), 203-220. https:// doi.org/10.1080/21532974.2019.1646169

Anggraini, D., Khumaedi, M., \& Widowati, T. (2020). Validity and reliability contents of independence assessment instruments of basic beauty students for class X SMK. Journal of Research and Educational Research Evaluation, 9(1), 40-46. https://doi.org/10.15294/jere.v9i1.42558

Baharuddin, B. (2018). ADDIE Model application promoting interactive multimedia. IOP Conference Series: Materials Science and Engineering, 306(1). https://doi.org/10.1088/1757-899X/306/1/012020

Barrett, T. (2017). A new model of problem-based learning: Inspiring concepts, practice strategies and case studies from higher education. AISHE.

Ceker, E., \& Ozdamli, F. (2016). Features and characteristics of problem based learning. Cypriot Journal of Educational Sciences, 11(4), 195-202. https://doi.org/10.18844/cjes.v11i4.1296

Ceroni, M. R., Carpigiani, B., Castanheiraa, M. P., \& Silva, A. A. (2016). The perception of teachers about students' potentialities and difficulties. Procedia - Social and Behavioral Sciences, 217, 958-966. https://doi.org/10.1016/j.sbspro.2016.02.070

Cheung, L. (2016). Using the ADDIE Model of Instructional Design to teach chest radiograph interpretation. Journal of Biomedical Education, 2016(1), 1-6. https:// doi.org/10.1155/2016/9502572

Cho, W., Jung, Y., \& Im, J. H. (2014). Students' evaluation of learning management system in the personal computer and smartphone computing environment. International Journal of Mobile Communication, 12(2), 142-159. https://doi.org/10.1504/IJMC.2014.059735

Creswell, J. W. (2012). Educational research: Planning, conducting, and evaluating quantitative and qualitative research, 4 th ed. Pearson.

Dreamson, N., Thomas, G., Hong, A. L., \& Kim, S. (2018). The perceptual gaps in using a learning management system: Indigenous cultural perspectives. Technology, Pedagogy and Education, 27(4), 1-14.

https:// doi.org/10.1080/1475939X.2018.1490665

Emmamoge, O., Bilkisu, H., Yahya, K., \& Ahmed, M. I. (2020). The impact of learning management system in Federal College of Forestry, Jos: A case study. IIARD International Journal of Geography and Environmental Management, 6(1), 60-72. https://iiardpub.org/get/IJGEM/VOL. 6 NO. 1 2020/The Impact of Learning.pdf 
Ferrari, A. (2012). Digital competence in practice: An analysis of frameworks. Publications Office of the European Union. Institute for Prospective Technological Studies (Joint Research Centre). https://doi.org/10.2791/82116

Guitert, M., Romeu, T., \& Colas, J. F. (2020). Basic digital competences for unemployed citizens: Conceptual framework and training model. Cogent Education, 7(1), 1-20. https://doi.org/10.1080/2331186X.2020.1748469

Gutman, M. (2017). Facilitating pre-service teachers to develop regulation of cognition with learning management system. Educational Media International, 54(3), 199-214. https://doi.org/10.1080/09523987.2017.1385164

He, Y. (2014). Universal design for learning in an online teacher education course: Enhancing learners' confidence to teach online. MERLOT Journal of Online Learning and Teaching, 10(2), 283-298. https://jolt.merlot.org/vol10no2/he_0614.pdf

Ilomäki, L., Paavola, S., Lakkala, M., \& Kantosalo, A. (2016). Digital competence: An emergent boundary concept for policy and educational research. Education and Information Technologies, 21(3), 655-679.

http://www.aijcrnet.com/journals/Vol_5_No_6_December_2015/10.pdf

Kean, A. C., Embi, M. A., \& Yunus, M. M. (2012). Incorporating ICT tools in an active engagement strategy-based classroom to promote learning awareness and self-monitoring. International Education Studies, 5(4), 139-149. https:// doi.org/10.5539/ies.v5n4p139

Kurniawati, J., \& Baroroh, S. (2016). Literasi media digital mahasiswa universitas Muhammadiyah Bengkulu [Digital media literacy for students of Bengkulu Muhammadiyah University]. Jurnal Komunikator, 8(2), 51-66. https://journal.umy.ac.id/index.php/jkm/article/view/2069

Marineo, F., \& Shi, Q. (2019). Supporting student success in the first-year experience: Library instruction in the learning management system. Journal of Library and Information Services in Distance Learning, 13(1-2), 40-55. https://doi.org/10.1080/1533290X.2018.1499235

Marty, P. F., Alemanne, N. D., Mendenhall, A., Maurya, M., Southerland, S. A., Sampson, V., Douglas, I., Kazmer, M. M., Clark, A., \& Schellinger, J. (2013). Scientific inquiry, digital literacy, and mobile computing in informal learning environments. Learning, Media and Technology, 38(4), 407-428. https://doi.org/10.1080/17439884.2013.783596

Mijatovic, I., Cudanov, M., \& Jednak, S. (2013). How the usage of learning management systems influences student achievement. Teaching in Higher Education, 18(5), 506-517. https://doi.org/10.1080/13562517.2012.753049

Mou, T., Jeng, T., \& Chen, C. (2013). From storyboard to story: Animation content development. Educational Research and Reviews, 8(13), 1032-1047. https:// doi.org/10.5897/ERR2013.1484

Nikat, R. F. (2020). Analisis kemampuan literasi teknologi calon guru fisika melalui online formative assessment [Analysis of technological literacy ability of prospective physics teachers through online formative assessment]. Quantum: Jurnal Inovasi Pendidikan Sains, 11(2), 112-122. https://doi.org/10.20527/quantum.v11i2.8739

Pöntinen, S., \& Räty-Záborszky, S. (2020). Pedagogical aspects to support students' evolving digital competence at school. European Early Childhood Education Research Journal, 0(2), 1-15. https:// doi.org/10.1080/1350293X.2020.1735736

Raza, S. A., Qazi, W., Khan, K. A., \& Salam, J. (2021). Social isolation and acceptance of the learning management system (LMS) in the time of COVID-19 pandemic: An expansion of the UTAUT Model. Journal of Educational Computing Research, 59(2), 183-208. https://doi.org/10.1177/0735633120960421 
Reinbold, S. (2013). Using the ADDIE Model in designing library instruction. Medical Reference Services Quarterly, 32(3), 244-256.

https://doi.org/10.1080/02763869.2013.806859

Rizal, R., Rusdiana, D., Setiawan, W., \& Siahaan, P. (2020a). Digital literacy test: Development of multiple choice test for preservice physics teachers. International Journal of Advanced Science and Technology, 29(3), 7085-7095. http://sersc.org/journals/index.php/IJAST/article/view/7567

Rizal, R., Rusdiana, D., Setiawan, W., \& Siahaan, P. (2020b). Creative thinking skills of prospective physics teacher. Journal of Physics: Conference Series, 1521(1), 1-6. https:// doi.org/10.1088/1742-6596/1521/2/022012

Rizal, R., Rusdiana, D., Setiawan, W., \& Siahaan, P. (2020c). The digital literacy of the first semester students in physics education. Jurnal Pendidikan Fisika Universitas Muhammadiyah Makassar, 8(2), 101-110. https://doi.org/10.26618/jpf.v8i2.3293

Rizal, R., Rusdiana, D., Setiawan, W., \& Siahaan, P. (2020d). Students' perception of learning management system supported smartphone: Satisfaction analysis in online physics learning. Jurnal Pendidikan IPA Indonesia, 9(4), 600-610. https://doi.org/10.15294/jpii.v9i4.25363

Rizal, R., Rusdiana, D., Setiawan, W., Siahaan, P., \& Ridwan, I. M. (2021). Gender differences in digital literacy among prospective physics teachers. Journal of Physics: Conference Series, 1806(1), 1-7. https://doi.org/10.1088/17426596/1806/1/012004

Rizal, R., Setiawan, W., \& Rusdiana, D. (2019). Digital literacy of preservice science teacher. Journal of Physics: Conference Series, 1157(2), 1-6. https:// doi.org/10.1088/1742-6596/1157/2/022058

Shopova, T. (2014). Digital literacy of students and its improvement at the university. Journal on Efficiency and Responsibility in Education and Science, 7(2), 26-32. https:// doi.org/10.7160/eriesj.2014.070201

Susilawati, S., Satriawan, M., Rizal, R., \& Sutarno, S. (2020). Fluid experiment design using video tracker and ultrasonic sensor devices to improve understanding of viscosity concept. Journal of Physics: Conference Series, 1521(2), 1-6. https://doi.org/10.1088/1742-6596/1521/2/022039

Tejedor, S., Cervi, L., Escoda, A. P., \& Jumbo, F. T. (2020). Digital literacy and higher education during COVID-19 lockdown: Spain, Italy, and Ecuador. MDPI Publications, 8(48), 1-17. https://doi.org/10.3390/publications8040048

Turnbull, D., Chugh, R., \& Luck, J. (2019). Learning management system: An overview. In A. Tatnall (Ed.), Encyclopedia of Education and Information Technologies (pp. 1-7). Springer Nature. https:/ / doi.org/10.1007/978-3-319-60013-0

Vuorikari, R., Punie, Y., Carretero, S., \& Van den Brande, L. (2016). DigComp 2.0: The digital competence framework for citizens. Publications Office of the European Union. Joint Research Centre (European Commission). https://doi.org/10.2791/11517 